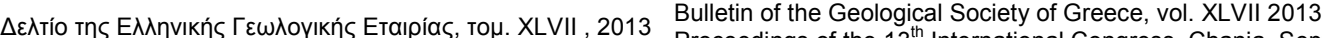
Xroceedings of the $13^{\text {th }}$ International Congress, Chania Sept.

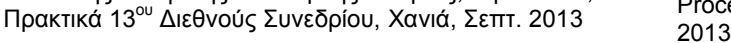

\title{
CLIMATIC VS TECTONIC CONTROL ON THE EARLY LATE MIOCENE TECTONO-STRATIGRAPHIC DEPOSITS OF THE PRE-APULIAN ZONE, WESTERN GREECE
}

\author{
Drinia H. ${ }^{1}$ \\ ${ }^{I}$ National and Kapodistrian University of Athens, Faculty of Geology and Geoenvironment, \\ Department of Hist. Geology - Paleontology, cntrinia@geol.uoa.gr
}

\begin{abstract}
Here, we elucidate the relationship between tectonics and climate and their influence on sedimentation. A number of marine sediment samples were collected from a section located in the northern margin of the Agios Petros Basin (Early Tortonian, Levkas Island, W. Greece) for micropalaeontological analysis, in order to establish and interpret of the palaeoenvironmental and palaeobathymetric changes. The distribution patterns of the dominant and associated benthic foraminiferal species (Siphonina reticulata and Cibicidoides kullenbergi), together with the decreased Benthic Foraminiferal Number (BFN) values, elevated diversities and higher planktonic-to-benthic ratios, suggest deposition at bathyal water depths with moderate organic matter fluxes and elevated oxygen contents of the bottom water, typical for this water depth interval. The early Late Miocene infilling of the Agios Petros basin is related to the westward advances of the Ionian zone which induced flexural loading and subsequent relative sea-level rise.
\end{abstract}

Key words: Early Tortonian, foraminifera, palaeobathymetry, tectonics, climate.

\section{Пєрі́ $\eta \psi \eta$}

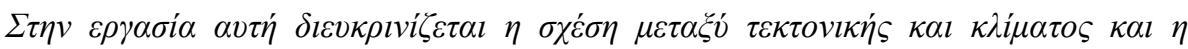

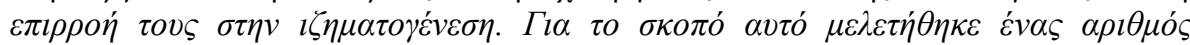

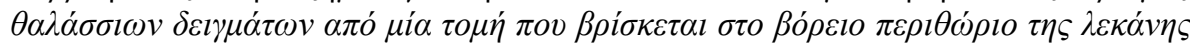

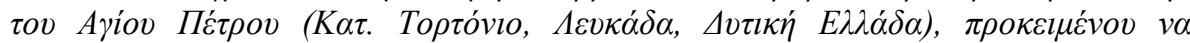

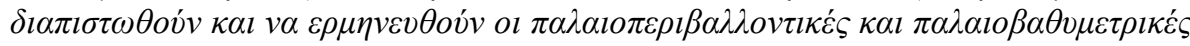

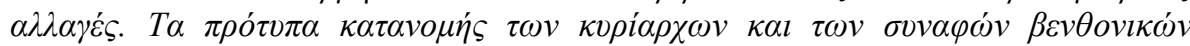

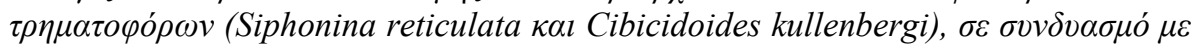

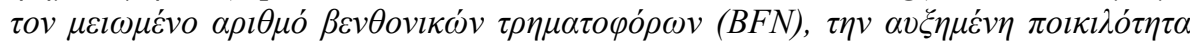

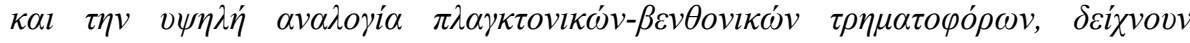

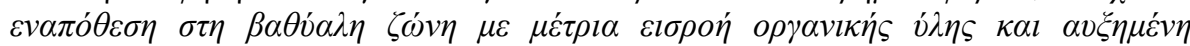

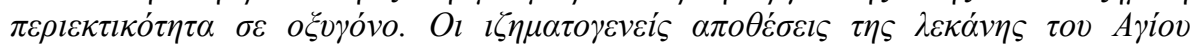

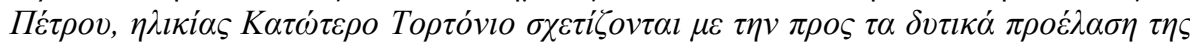

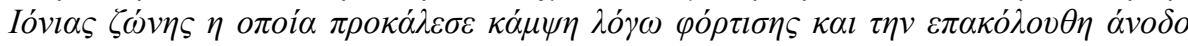
$\tau \eta \varsigma \sigma \chi \varepsilon \tau \imath \kappa \eta ่ \varsigma ~ \sigma \tau \dot{\alpha} \theta \mu \eta \varsigma \tau \eta \varsigma ~ \theta \dot{\alpha} \lambda \alpha \sigma \sigma \alpha \varsigma$.

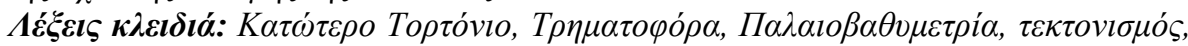
$\kappa \lambda i \mu \alpha$. 


\section{Introduction}

Ionian Islands in western Greece represent one of the most tectonically active regions of the Eastern Mediterranean. They constitute part of the para-autochthonous Apulian foreland of the Hellenide orogen and include rocks of the Pre-Apulian (or Paxos) and Ionian isopic zones (Aubouin, 1957; 1965; Underhill, 1989). The Pre-Apulian or Paxos zone corresponds to mixed neritic/pelagic sedimentation, reaching into the Aquitanian, overlain by Miocene marl sequence. This zone was previously regarded as the undeformed Hellenides foreland but more recent work revealed that it was dominated by shortening during Tertiary-Quaternary times (Underhill, 1989).

In Levkas Island, the Pre-Apulian zone is represented in Agios Petros area which covers the southwestern part of the island and is separated from the Ionian limestones by a major NE-SW oriented thrust fault, known as the Ionian or Kalamitsi Thrust (Figure 1).

In spite of some general studies carried out by Bornovas (1964) and de Mulder (1975), little attention has been directed to the Miocene infill of the Agios Petros Basin (Cushing, 1985; Rondoyanni-Tsiambaou, 1997) which is marked by a fundamental change in its palaeogeographic configuration: at about the transition Oligocene-Miocene, the pre-existing shallow platform with flourishing larger foraminiferal faunas subsided and marls and clays which point to quiet sedimentation conditions with only subordinate supply of displaced coarser material were deposited until the Late Miocene (Bornovas, 1964; de Mulder, 1975).

The purpose of this study is to establish the magnitude of palaeoenvironmental and palaeobathymetric changes and to explore the possible causes that led to these changes, throughout the Early Tortonian part of the pre-Apulian zone from Levkas Island, by means of benthic foraminiferal analysis. This study represents the prosecution of a more general stratigraphic/ palaeoecological work carried out on the same section (Drinia et al., 2007). In the previous paper, the microfossil content (benthic foraminifera) of the Manassi section has been described revealing that deposition took place in upper to middle bathyal depths, during a period of intense tectonic activity. However, this study does not give an adequate representation of the depositional history of the Early Tortonian sediments across the Agios Petros Basin and does not provide possible explanations for changes in sea level.

\section{Study Location and Methods}

The studied section, which is proximal to the Kalamitsi thrust fault, is located on the eastern slope of a N-S running valley, near the village of Manassi (Figure 1). The succession consists of blue grey marls and clays with some fine grained sandstone interbeds. The intercalations of these thin, clastic beds and especially of positively graded sandstones in the studied succession reflect the influence of density currents, which supplied coarser material from a distant hinterland (de Mulder, 1975). The Manassi section is the only section in the environs of the thrust fault that is entirely exposed in outcrop, where closely packed stratigraphic samples can be undertaken. Yet, at $17 \mathrm{~m}$ of the record, an erosional hiatus is implied (Figure 2). The detailed biostratigraphy is retained as reported in Drinia et al. (2007) and Antonarakou (2010). In accordance with these authors, the section covers the time interval between 11.54 and 11.2 Ma, having a lower Tortonian age, above the Serravallian/Tortonian boundary (Paragloborotalia siakensis planktonic foraminiferal zone).

A total of 26 samples (391-1 to 391-26) were re-examined from the micropalaeontological point of view. The data set was recovered from Drinia et al. (2007).

Based on the faunal counts, benthic foraminiferal numbers (BFN; number of specimens per gram dry sediment) were re-calculated with a view to cross - check with the already published values in Drinia et al. (2007). The reason for the revised values has been brought about by the fact that BFN number gives information on the taphonomy of the original living assemblage, the oxygen level (e.g. Ernst \& van der Zwaan, 2004), the energy level in which the sediments were deposited (high

$\underline{\text { XLVII, No } 1-93}$ 
abundance in low energy), and to a minor extent the productivity or organic flux (Ernst \& van der Zwaan, 2004). Species diversity of benthic foraminifera was estimated by the Fisher $\alpha$ index $(\alpha)$, using the program "PAST" of Hammer et al. (2001).

Moreover, the percentage of planktonic species in the total foraminiferal association $(\% \mathrm{P})$ calculated as $100 * \mathrm{P} /(\mathrm{P}+\mathrm{B})$ and retained from Drinia et al. (2007), was used in order to reconstruct palaeodepth and track sea-level changes.

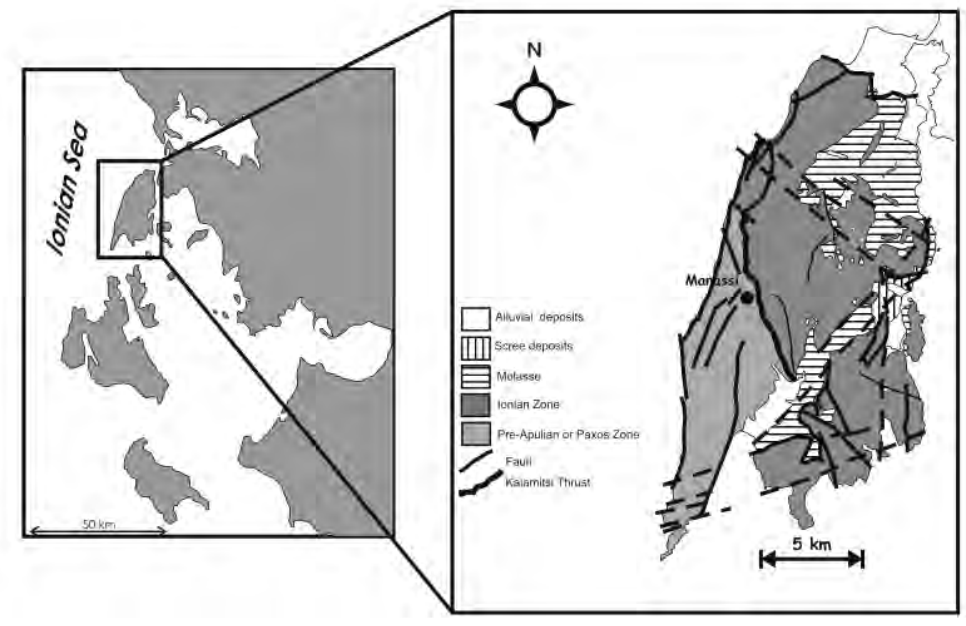

Figure 1 - Geological map of Levkas island, showing the location of the section studied.

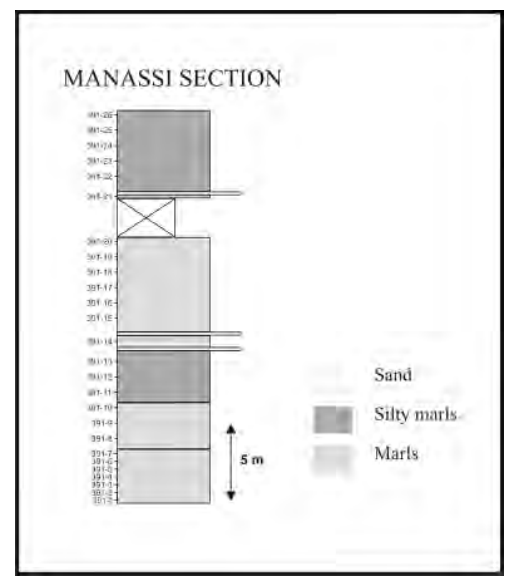

Figure 2 - Stratigraphic column of the measured section.

\section{Results and Analysis}

\subsection{Benthic Foraminiferal Trends}

Figure 3 shows the frequency of the dominant benthic species in the samples as this is reported in Drinia et al. (2007). The most abundant species recovered from the section were Siphonina reticulata, Cibicidoides kullenbergi, Melonis barleeanum, Cibicidoides italicus. These taxa abundantly and persistently occur from the base of the section up to the level of $14 \mathrm{~m}$ and from 20 to $22 \mathrm{~m}$, along with Globocassidulina subglobosa, Gyroidinoides neosoldanii and Uvigerina semiornata rutila, representing a fairly diverse open marine association. These benthic taxa are 
commonly found in open marine Mediterranean environments of late Miocene age (Kouwenhoven et al., 2006), and are characterized by their mutual preference for well - oxygenated environments with normal salinity (Lutze, 1977; van der Zwaan, 1982; Lutze \& Thiel, 1989; Verhallen, 1991; Sjoerdsma \& van der Zwaan, 1992; Kaiho, 1994; Sgarrella et al., 1999; Kouwenhoven \& van der Zwaan, 2006). High abundances of $S$. reticulata seem to coincide with periods of relatively cooler and more dense surface waters and thus enhanced deep - water mixing and circulation (Sgarrella et al., 1999).

The marked occurrence of Globocassidulina subglobosa in the lower part of the record suggests an environment with low organic matter flux.

The upper part of the record marks an abrupt faunal change in the benthic foraminiferal assemblage. The benthic assemblage in this interval constitutes a new fauna with a subordinate component of Cibicidoides taxa. Elphidium spp., Cibicides lobatulus, Cibicides refulgens and Asterigerinata planorbis are highly abundant from 15 to $17 \mathrm{~m}$, at $19.95 \mathrm{~m}$ and from 23.2 to $24.2 \mathrm{~m}$ where they exceed $50 \%$ of total abundance. These species are reported to live in shallow shelf areas generally above $200 \mathrm{~m}$ (Murray, 1991; Seidenkratz et al., 2000), but they are also found in greater depths to which they are often transported passively. These species are extremely tolerant and adaptable to large variations in temperature, salinity and food supply (Linke \& Lutze, 1993). The abundance of these species is considered as an indication of erosional processes from shallow shelf seas and therefore not a part of the fossil community.

BFN (Figure 3) remains relatively stable exhibiting low values apart from the lower part of the record, at $1.2 \mathrm{~m}$, where BFN shows an abrupt increase (from 2110 to 12800). The diversity of the benthic foraminiferal assemblage varies from $22-50$ benthic foraminiferal taxa per $\sim 200$ counted specimens. The Fisher diversity index (alpha index) (Figure 3), representing the assemblage diversity, fluctuates between 9 and 21 over the sampled interval, fluctuating in between 10 and 15 . In general, from the base of the section up to $6.2 \mathrm{~m}$, diversity is relatively low with a mean value alpha=13. Two samples, i.e. at 7.2 and $12 \mathrm{~m}$, show unusually high alpha index. The Fisher diversity index for the rest of the succession is distinctly lower compared (for the interval from 13 to $23.2 \mathrm{~m}$ : alpha values vary between 13.5 and 19, Figure 3). Higher up, the Fisher diversity index further decreases, reaching a value around 10 .

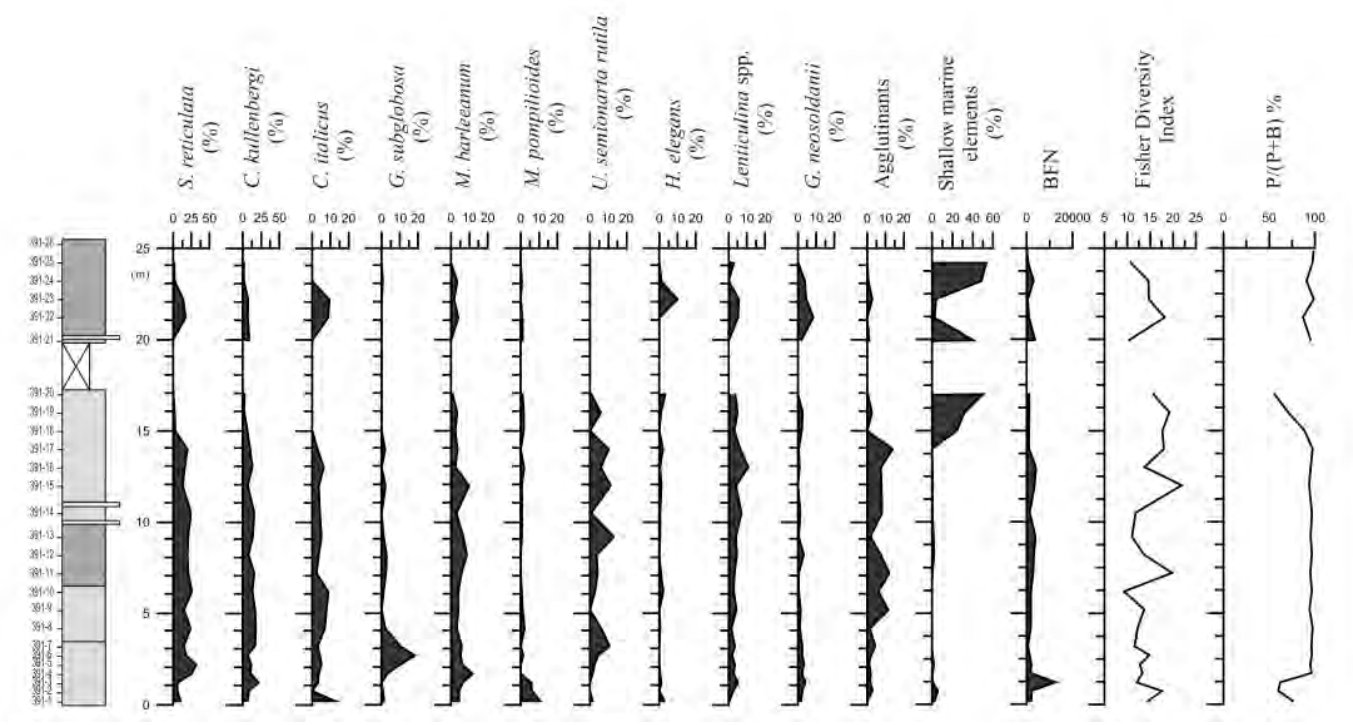

Figure 3 - Occurrence and relative abundance of the most characteristic benthic foraminiferal groups in the studied section together with faunal parameters $(\mathrm{BFN}, \mathrm{P} / \mathrm{P}+\mathrm{B} \%$, Fisher-a diversity).

$\underline{\text { XLVII, No } 1-95}$ 
The result of planktonic percentage analyses performed in this study is shown graphically in Figure 3. Planktonic/benthic ratios vary between 55 and $98 \%$ of the benthic assemblage. The common occurrence of planktonic foraminifera, throughout the succession, suggests open marine connections to the oceanic realm. With the exception of samples 391-1 to 391-3 and 391-20, the planktonic percentage in all observed Manassi samples is greater than 90. According to data compiled by Murray (1991) and van der Zwaan et al. (1990) this relates to an average water depth of about $1000 \mathrm{~m}$ (lower bathyal zone).

\section{Discussion}

\subsection{Palaeoenvironmental Significance of the Benthic Foraminiferal Parameters}

In the early Tortonian Manassi section the distribution patterns of the dominant and associated species ( $S$. reticulata and C. kullenbergi), together with the decreased BFN values, elevated diversities and higher planktonic-to-benthic ratios, suggest deposition at bathyal water depths with moderate organic matter fluxes and elevated oxygen contents of the bottom water, typical for this water depth interval (e.g. Schmiedl et al., 1997).

Relatively high diversity values, with Fisher- $\alpha$ more than 10 also support a bathyal environment of deposition. According to Murray (1991) and Hayward (1986), diversity in benthic foraminifera in modern foraminiferal assemblages reaches a maximum in upper bathyal assemblages with values of Fisher- $\alpha$ index typically in the range of 20-30.

However, at $1.2 \mathrm{~m}$ of the record, there is a horizon with higher benthic foraminiferal content (abrupt increase in BFN value, Figure 3). This horizon also contains other shallow-water debris, such as echinoid spines and gastropods and is interpreted as a turbidite sourced from a shallower water environment. Another reason for this abrupt increase in the abundance of benthic foraminifera could have a secondary, taphonomic origin, which would imply that the original benthic foraminiferal assemblage is best preserved in this level and that the remainder of the section does suffer from preferential dissolution. However, the actual assemblage quality (in situ fauna) is identical to other levels, and there is no evidence that dissolution-sensitive species are better preserved in this level.

\subsection{Estimating Palaeobathymetry Using Benthic Foraminiferal Census Data}

Palaeobathymetry curve presented for Manassi section in Figure 4 is based on quantitative benthic foraminiferal census data reported by Drinia et al. (2007). To estimate the depositional depth of the sediments, the general relationship between depth and the fraction of planktonic foraminifera with respect to the total foraminiferal population (\%P) (van der Zwaan et al., 1990) was used, following sample selection and counting procedures described in van Hinsbergen et al. (2005). If samples with evidence for downslope transport and carbonate dissolution are discarded, the relationship between \%P and depth of van der Zwaan et al. (1990) allows the estimation of the depositional depth of sediments with approximately $50 \mathrm{~m}$ of uncertainty at levels of a few hundreds of metres, to $150 \mathrm{~m}$ at depths around $1 \mathrm{~km}$.

According to the palaeobathymetric curve and as reported by DRINIA et al. (2007), deposition began at $\sim 530 \mathrm{~m}$ (deep upper bathyal) during the deposition of sample 391-1 and regressed to $\sim 340 \mathrm{~m}$ (upper bathyal) in sample 391-3. The sea then transgressed to a palaeodepth of $\sim 1130 \mathrm{~m}$ (deep lower middle bathyal) during the deposition of sample 391-17. An ensuing rapid regression saw sea-levels attain a palaeodepth $\sim 270 \mathrm{~m}$ (upper bathyal) during the deposition of sample 39120. At $17 \mathrm{~m}$, just above sample 391-20, an erosional hiatus, associated with shoaling conditions that caused the change in foraminiferal assemblages, is implied. Indeed, declining Cibicidoides, Siphonina and Cassidulina abundances coupled with increasing Elphidium and A. planorbis abundances indicate a shallowing from the outer neritic to bathyal zone to the middle neritic zone, 
with shallowing continuing to inner neritic depths. However, the high percentage of planktonics indicate download transport and mixing with the bathyal fauna.

Based on the constructed palaeobathymetric curve, the sea then transgresses abruptly to $\sim 1100 \mathrm{~m}$ (deep middle bathyal) at the time of sample 391-21 and remained relatively constant with shortterm fluctuations from sample 391-22 till 391-25.

\subsection{Differentiating Glacio-eustasy and Tectonics}

The palaeobathymetric evolution of the studied sediments together with the faunal pattern as this is presented in Figure 3 provide the key to unlocking the broader question as to whether the depositional pattern within this part of the Agios Petros Basin was driven by tectonic or eustatic change. It is frequently difficult to separate the contributory effects of eustatic and tectonic change as they usually act in concert.

\subsubsection{Eustatic Control}

Based on the biostratigraphy, the studied sequence has been deposited just above the global sequence boundary Ser4/Tor1, dated at $11.7 \mathrm{Ma}$, which represents a low sea-level event, corresponding to MSi-4 oxygen cooling event of Abreu \& Anderson (1998) which is time equivalent to Mi5 cooling event of Miller et al. (1991), (Figure 5).

However, the tentative sea-level curve for the Manassi section generally corresponds to a transgressive event. This differentiation from the global sea level trend may suggest that some other controls have affected sedimentation prior to and during the Manassi sedimentation. Such controls may involve external/allocyclic or internal/autocyclic factors, such as relative sea-level changes, tectonics, basement topography (shape and size of the basin), character of the source area and sedimentary processes within the receiving basin, most of which are interactive.

To identify possible relationships between palaeodepth variation on the Manassi record, sea level changes and/or tectonic events, the palaeodepth curve is compared with the global $\delta 180$ record of Zachos et al. (2001). Oxygen isotopes provide a minimum estimate for absolute sea level changes, by interpreting the amplitude of $\delta 18 \mathrm{O}$ variation and assuming a constant ice volume effect. Hence, an increase in $\delta 180$ suggests increased ice volume and hence the associated sea level fall and depletion in $\delta 180$ corresponds to high sea-level stands. Integration of all these different parameters leads to a robust palaeobathymetric reconstruction of the early Tortonian Manassi succession.

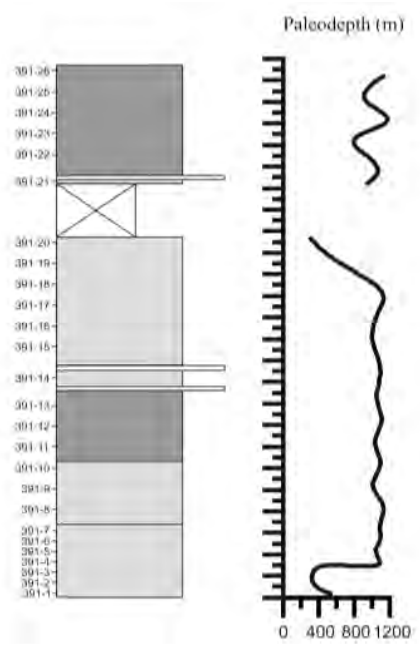

Figure 4 - Palaeobathymetric curve of the studied section, based on quantitative benthic foraminiferal census data (Drinia et al. 2007).

XLVII. No 1 - 97 


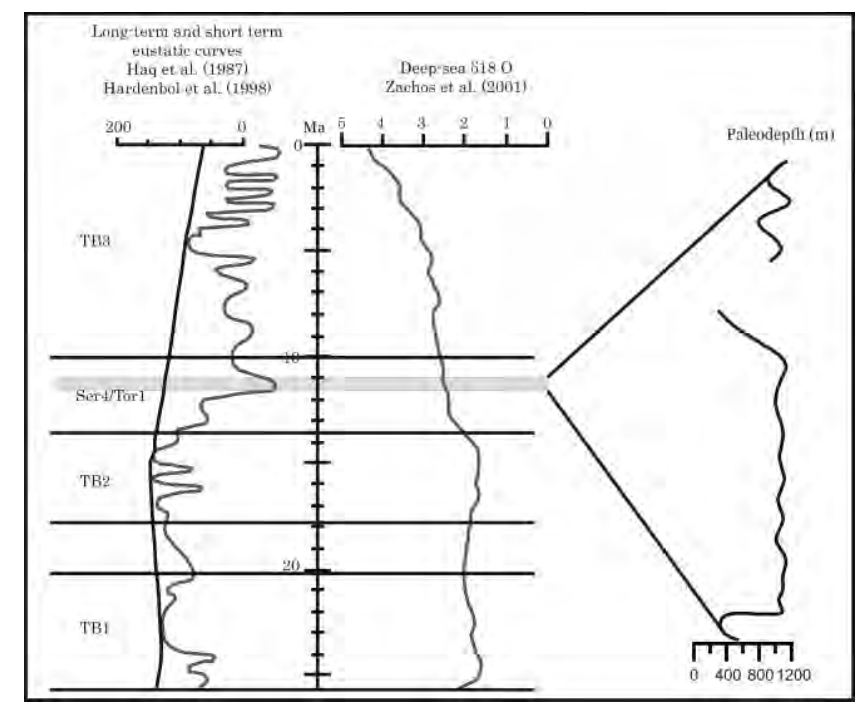

Figure 5 - Comparison of the reconstructed palaeodepth curve with the isotope record of Zachos et al. (2001) and the eustatic curves of Haq et al. (1987) and Hardenbol et al. (1998).

Comparison between the palaeodepth curve and the isotopic record shows opposite trend of the two curves throughout the investigated interval. The isotope record shows a positive excursion coinciding with the shallowing trend in the eustatic curve. This correspondence contradicts with the transgressive event which has taken place during that period, in Levkas Island. According to Flecker et al. (1995), during the Early Tortonian, the transgression and rapid relative sea-level rise that affected at least a large area of the Eastern Mediterranean are regional events rather than being the local effects of small scale tectonic activity within individual basins.

However, the presence of abrupt depth changes may reflect an increased tectonic activity during this interval. In addition, high amplitude fluctuation of the water depth at the upper part of the Manassi section was probably caused by fluxes of sediment from shallower parts of the basin with excess benthic foraminifera, which make the estimation shallower than the actual water depth.

\subsubsection{Tectonic Control}

The studied sediments at the northern part of the Agios Petros Basin represent part of the PreApulian zone which has been deposited from 11.54 to $11.21 \mathrm{Ma}$, a time interval which corresponds to a phase of compression and flexural subsidence which affected the external Ionian Zone and the Pre-Apulian Zone in Levkas island (Meulenkamp, 1982; van Hinsbergen et al., 2006; Accordi et al., 1998; Karakitsios \& Rigakis, 2007). According to Clews (1989), at the end of the Early Miocene the Kalamitsi Thrust became active and caused uplift and erosion across the basin. Although the Kalamitsi thrust was active in the early Miocene (Clews 1989), extensional growth faulting in the Pre-Apulian zone continued through to early Pliocene times (Sorel 1976) and acted as a major control on sedimentary patterns. Marine transgression was due to this extensional faulting, in response to load-induced flexure resulting from thrusting of the Ionian zone to the west. The rapid subsidence event is attributed to the formation of a deep, underfilled foreland basin caused by continued thrusting. During this period, the Pre-Apulian zone became increasingly dominated by clastic influences.

The detailed study of the Miocene sediments of the Manassi section reveals that at certain levels within the succession, events such as uplift had occurred in the hinterland. This is indicated by the generally higher influx of quartz in samples 391-21 to 391-26, and is further supported by the high percentages of inner neritic taxa indicating that marginal marine and continental influxes became overwhelmingly dominant.

$\underline{\text { XLVII, No } 1 \text { - } 98}$ 
The fraction of transported benthic foraminiferal species relative to the total amount of benthic foraminifera can be also used as an indication of relative sea level (Figure 4). The lower half part of the section is dominated by outer neritic and oceanic taxa, indented by small excursions of inner neritic ecological groups, reflecting relatively outer neritic to open marine conditions. From 15 to $17 \mathrm{~m}$ and at $19.95 \mathrm{~m}$, an upward increase of inner neritic benthic foraminifera indicates increasing influence of marginal marine settings. Slightly higher in the record, the composition of the benthic foraminifera association changes again abruptly and becomes dominated by outer neritic - bathyal taxa.

\subsection{Subsidence History}

In this work it is not our intention to reconstruct the subsidence history and relative sea level for the studied area as this is not possible as we miss tie points of stratigraphy (primarily boundaries of nannozones and stages). However, some general implications can be made. Subsidence history based on the palaeobathymetric estimations shows that the development of depositional depth in the Manassi section was primarily determined by tectonics. That is the general sea level rise trend in the Agios Petros Basin has been caused by tectonically induced subsidence.

In the lower part of the record minor amplitude, short duration uplift may be due to local reorientation of stress field takes place followed by a rapid, high rate subsidence. The stratigraphic interval from 1.7 to $14 \mathrm{~m}$ is characterized by a relative long period of tectonic quiescence. From 14 to $17 \mathrm{~m}$, significant uplift took place due to regional compression. This points to a radical change in early Tortonian basin evolution. However, the strange looking drop and jump of the basin and seafloor maybe an artefact, probably caused by an overestimation of palaeowater depth. This compressive event resulted in the formation of a sedimentary gap (from 17 to $20 \mathrm{~m}$ )

\section{Conclusions}

The main objective of this study was the interpretation and documentation of the factors that led to changes in relative sea level of the early Late Miocene tectono-stratigraphic deposits of the PreApulian zone, in Levkas Island, Western Greece. Moreover, we attempted to integrate the estimated palaeobathymetric trend into a wider, global context of sea level changes.

Previous work of Drinia et al. (2007) revealed that the distribution patterns of the dominant and associated benthic foraminiferal species together with the estimated faunal parameters, suggest a bathyal depositional environment.

The palaeodepth history of this part of the Pre-Apulian Foreland Basin as revealed by the comparison of the tentative sea level curve with the global $\delta 18 \mathrm{O}$, is mainly dominated by tectonics and not by eustatic signal.

Flexural loading is inferred to have resulted in regional tectonic subsidence and consequently in relative sea- level rise.

\section{Acknowledgments}

Financial support for this research was provided by the Research Project 70/4/11078 of the University of Athens. The author wishes to thank Prof. V. Karakitsios and an anonymous reviewer for their constructive comments that helped improve the manuscript.

\section{References}

Abreu V.S. and Anderson J.B. 1998. Glacial eustasy during the Cenozoic: sequence stratigraphic implications, American Association Petroleum Geologist Bulletin, 82, 1385-1400.

Accordi G., Carbone F. and Pignatti J. 1998. Depositional history of a Palaeogene carbonate ramp (Western Cephalonia, Ionian Islands, Greece), Geologica Romana, 34, 131-205. 
Antonarakou A. 2010. Plankton Biostratigraphy and palaeoclimatic implications of an early Late Miocene sequence of Levkas island, Ionian Sea, Greece, Bulletin of the Geological Society of Greece, XLIII, 568 - 578.

Aubouin J. 1957. Essai de corrélation stratigraphique de la Grèce occidentale, Bulletin de la Societé Géologique de France, 7, 281-304.

Aubouin J. 1965. Geosynclines, Developments in Geotectonics, 1 - 335, Elsevier, Amsterdam,

Bornovas J. 1964. Géologie de l'île de Lefkade, Geological and Geophysical Research (I.G.S.R), $10,1-142$.

Clews J.E. 1989. Structural controls on basin evolution: Neogene to Quaternary of the Ionian zone, Western Greece, Journal of the Geological Society, London, 146, 447-457.

Cushing M. 1985. Evolution structurale de la marge nord oust hellénique dans l'île de Levkas et ses environs (Grèce nord occidentale), Unpublished Thèse 3me cycle, Université de ParisSud, Centre d' Orsay.

De Mulder E.F.J. 1975. Microfauna and sedimentary-tectonic history of the Oligo-Miocene of the Ionian Islands and Western Epirus (Greece), Utrecht Micropalaeontological Bulletins, 13, $1-139$.

Drinia H., Antonarakou A., Kontakiotis G., Tsaparas N., Segou M. and Karakitsios V. 2007. Palaeobathymetric Evolution of the Early Late Miocene Deposits of the Pre-Apulian Zone, Levkas Island, Ionian Sea, Bulletin of the Geological Society of Greece, 40, 39-52.

Ernst S. and Van der Zwaan B. 2004. Effects of experimentally induced raised levels of organic flux and oxygen depletion on a continental slope benthic foraminiferal community, DeepSea Research I, 51, 1709-1739.

Jorissen F.J., de Stigter H.C. and Widmark J.G.V. 1995. A conceptual model explaining benthic foraminiferal microhabitats, Marine Micropalaeontology, 26, 3-15.

Flecker R., Robertson A.H.F., Poisson A. and Müller C. 1995. Facies and tectonic significance of two contrasting Miocene basins in south coastal Turkey, Terra Nova, 7, 221-232.

Hammer Ø., Harper D.A.T. and Ryan P.D. 2001. PAST: palaeontological statistics software package for education and data analysis, Palaeontologia Electronica, 4, 9 p.

Hayward B.W. 1986. A guide to palaeoenvironmental assessment using New Zealand Cenozoic foraminiferal faunas, New Zealand Geoogical Survey Report PAL, 109, 73 p.

Kaiho K. 1994. Benthic foraminiferal dissolved - oxygen levels in the modern ocean, Geology, 22, $719-722$.

Karakitsios V. and Rigakis N. 2007. Evolution and Petroleum Potential of Western Greece, Journal of Petroleum Geology, 30, 197-218.

Kouwenhoven T.J. and Van der Zwaan G.J. 2006. A reconstruction of late Miocene Mediterranean circulation patterns using benthic foraminifera, Palaeogeography Palaeoclimatology Palaeoecology, 238, 373-385.

Kouwenhoven T.J., Morigi C., Negri A., Giunta S., Krijgsman W. and Rouchy J.M. 2006. Paleoenvironmental evolution of the eastern Mediterranean during the Messinian: Constraints from integrated microfossil data of the Pissouri Basin (Cyprus), Marine Micropaleontology, $60,17-44$.

Linke P. and Lutze G.F. 1993. Microhabitat preferences of benthic foraminifera - a static concept or a dynamic adaptation to optimize food aquisition? Marine Micropalaeontology, 20, 215234.

Lutze G.F. 1977. Neogene benthonic foraminifera from Site 369, Leg 41 DSDP, Initial Reports of the Deep Sea Drilling Project, 41, 659 - 666.

Lutze G.F. and Thiel H. 1989. Epibenthic foraminifera from elevated microhabitats: Cibicidoides wuellerstorfi and Planulina ariminensis, Journal of Foraminiferal Research, 19, 153 - 158.

Miller K.G., Wright J.D. and Fairbanks R.G. 1991. Unlocking the icehouse: Oligocene-Miocene oxygen isotope, eustacy, and margin erosion, Journal of Geophysical Research, 96, 68296848.

Meulenkamp J.E. 1982. On the pulsating evolution of the Mediterranean, Episodes, 1, 13-16. 
Murray J.W. 1991. Ecology and Palaeoecology of Benthic Foraminifera. Harlow, Essex, UK, Longman Scientific and Technical Publishers, 1-451.

Rondoyanni-Tsiambaou Th. 1997. Les séismes et l'environnement géologique de l'île de Lefkade, Grèce: Passé et Future, in: Marinos G., Koukis G., Tsiambaos Th. and Stournaras G. (Eds), Engineering Geology and the Environment, Paper presented at the International Symposium on Engineering Geology and the Environment, A.A. Balkema, Rotterdam, 1469-1474.

Seidenkrantz M.S., Kouwenhoven T.J., Jorissen F.J., Shackleton N.J. and Van der Zwaan G.J. 2000. Benthic foraminifera as indicators of changing Mediterranean-Atlantic water exchange in the late Miocene, Marine Geology, 163, 387-407.

Schmiedl G., Mackensen A. and Müller P.J. 1997. Recent benthic foraminifera from the eastern South Atlantic Ocean: dependence on food supply and water masses, Marine Micropalaeontology, 32, 249-288.

Sgarrella F., Sprovieri R., Di Stefano E., Caruso A., Sprovieri M. and Bonaduce G. 1999. The Capo Rossello borehole (Agrigento, Sicily) cyclostratigraphic and paleoceanographic reconstructions from quantitative analysis of the Zanclean foraminiferal assemblages, Rivista Italiana di Paleontologia e Stratigafia, 105, 303 - 322.

Sjoerdsma P.G. and van der Zwaan G.J. 1992. Simulating the effect of changing oceanic flux and oxygen content on the distribution of benthic foraminifers, Marine Micropaleontology, 19, $163-180$.

Sorel D. 1976. Etude néotectonique des iles ioniennes de Cephalonie et Zante et de l' Epire occidentale (Grèce), Thèse du $3^{e}$ cycle, Université de Paris-Sud, Centre d' Orsay.

Underhill J.R. 1989. Late Cenozoic deformation of the Hellenic foreland, Western Greece, Geological Society of America Bulletin, 101 613-634.

Van der Zwaan G.J. 1982. Paleoecology of late Miocene Mediterranean foraminiferam, Utrecht Micropaleontological Bulletins, 25. 201 pp.

Van der Zwaan G.J., Jorissen F.J. and De Stigter H.C. 1990. The depth dependency of planktonic/benthonic foraminiferal ratios: constraints and applications, Marine Geology, 95, 116.

Van der Zwaan G.J., Duijnstee I.A.P., Den Dulk M., Ernst S.R., Jannink N.T. and Kouwenhoven T.J. 1999. Benthic foraminifers: proxies or problems? A review of palaeocological concepts, Earth Science Revues, 46, 213-236.

Van Hinsbergen D.J.J., Kouwenhoven T.J. and Van der Zwaan G.J. 2005. Palaeobathymetry in the backstripping procedure: Correction for oxygenation effects on depth estimates, Palaeogeography Palaeoclimatology Palaeoecology, 221 245-265.

Van Hinsbergen D.J.J., Van der Meer D.G., Zachariasse W.J. and Meulenkamp J.E. 2006. Deformation of western Greece during Neogene clockwise rotation and collision with Apulia, International Journal of Earth Science, 95, 463-490.

Verhallen P.J.J.M. 1991. Late Pliocene to early Pleistocene Mediterranean mud - dwelling foraminifera; influence of changing environment on community structure and evolution, Utrecht Micropaleontological Bulletins, 40, 219 pp.

Zachos J., Pagani M., Sloan L., Thomas E. and Billups K. 2001. Trends, rhythms, and aberrations in global climate 65 Ma to present, Science, 292, 686-93. 